\title{
RAPID ONSET SENSORINEURAL HEARING LOSS SECONDARY TO BILATERAL CEREBRAL MELANOMA METASTASES TO THE CEREBELLOPONTINE ANGLE
}

\author{
Rhona Sproat ${ }^{1}$, Mahmood F. Bhutta², Neil Rane ${ }^{3}$, Pablo Martinez-Devesa ${ }^{4}$ \\ ${ }^{1}$ ENT Department, Wexham Park Hospital, U.K. \\ ${ }^{2}$ ENT Department, John Radcliffe Hospital, and Research Fellow, Nuffield Department of Surgery (University of \\ Oxford), Oxford, U.K. \\ ${ }^{3}$ Neuroradiology Department, John Radcliffe Hospital, Oxford, U.K. \\ ${ }^{4}$ ENT Department, John Radcliffe Hospital, Oxford, U.K.
}

Corresponding author: Rhona Sproat, ENT Department, Wexham Park Hospital, Wexham, Slough, Berkshire, SL2 4HL, U.K., Phone number: +44 01753633 000; .e-mail: rhonasproat@gmail.com

\begin{abstract}
Background: We describe a case of bilateral cerebellopontine angle melanoma metastases in the context of a literature review. The case is a rare presentation of sensorineural hearing loss and an unusual site of metastasis for malignant melanoma.

Methods and results: A 54-year-old man presented with sudden deafness. Bilateral melanoma metastases were confirmed with MRI and lumbar puncture. He died 3 months after treatment.

Conclusions: Melanoma metastasis should be considered as a differential for sensorineural hearing loss. A review of the literature found that the median survival of patients with bilateral cerebellopontine angle metastatic melanoma is 6 months posttreatment. At surgery these tumours are largely unresectable from cranial nerves VII and VIII. Surgical intervention is unlikely to result in survival or symptomatic benefit and the focus of treatment should be on maintaining quality of life. Hearing rehabilitation and gamma knife surgery may have a role.
\end{abstract}

Keywords: hearing • melanoma • cerebellopontine

\section{LA SORDERA SÚBITA A CONSECUENCIA DE METÁSTASIS BILATERAL DEL MELANOMA EN EL ÁNGULO PONTO-CEREBELOSO}

\section{Resumen}

Introducción: Se describe el caso de la metástasis bilateral del melanoma en el ángulo ponto-cerebeloso. Este punto puede ser una fuente de la pérdida auditiva de tipo de recepción y un punto raro de la presencia de la metástasis del melanoma maligno.

Métodos y resultados: Estudio del caso de un hombre de 54 años de edad, que había experimentado la sordera súbita. En base a la prueba MRI (de resonancia magnética) y de la punción lumbar, se ha encontrado la metástasis bilateral del melanoma. El paciente falleció a los tres meses después de la finalización del tratamiento médico

Resultados: La metástasis del melanoma se debe tratar como una causa más de la pérdida auditiva de tipo de recepción. Una revisión de la literatura especializada muestra que el tiempo medio de supervivencia de los pacientes con metástasis bilateral del melanoma en el ángulo ponto-cerebeloso es de 6 meses después del tratamiento médico. Estos tumores son en gran parte no operacionales e imposibles de separar a través de la cirugía de los nervios craneales del grupo VII y VIII. La intervención cirúrgica no aumenta la probabilidad de supervivencia o beneficio sintomático. El tratamiento debe centrarse en mantener la calidad de vida. La rehabilitación de la audición y la radiocirugía pueden traer resultados positivos.

Palabras clave: audición • melanoma • ángulo ponto-cerebeloso 


\section{ВНЕЗАПНАЯ ГЛУХОТА ВСЛЕДСТВИЕ ДВУСТОРОННИХ МЕТАСТАЗОВ МЕЛАНОМЫ В МОСТО-МОЗЖЕЧКОВОМ УГЛУ}

\section{Изложение}

Введение: Мы описываем случай двусторонних метастазов меланомы в мосто-мозжечковом углу. Это место может быть источником тугоухости нейросенсорного типа и редкой точкой наличия метастазов злокачественной меланомы.

Методы и результаты: Исследование на основании случая 54-летнего мужчины, у которого появилась внезапная глухота. Двусторонние метастазы меланомы обнаружены на основании исследования MRI и люмбальной пункции. Пациент умер через три месяца после окончания терапии.

Результаты: К метастазам меланомы следует подходить как к дополнению нейросенсорной тугоухости. Из обзора специалистической литературы следует, что среднее время выживаемости пациентов с двусторонними метастазами меланомы составляет 6 месяцев после окончания терапии. Эти опухоли в большой степени неоперабельные, отделить их от черепных нервов группы VII и VIII хирургически невозможно. Хирургическое вмешательство не повышает вероятности выживаемости и не увеличивает симптоматической пользы. Лечение должно сосредоточиться на поддержке качества жизни. Реабилитация слуха и радиохирургия могут принести положительные результаты.

Ключевые слова: слух • меланома • мосто-мозжечковый угол

\section{NAGLA GŁUCHOTA WYNIKIEM OBUSTRONNYCH PRZERZUTÓW CZERNIAKA W KĄCIE MOSTOWO-MÓŻDŻKOWYM}

\section{Streszczenie}

Wprowadzenie: Opisujemy przypadek obustronnych przerzutów czerniaka w kącie mostowo-móżdżkowym. Miejsce to może być źródłem niedosłuchu typu odbiorczego i rzadkim punktem występowania przerzutów czerniaka złośliwego.

Metody i wyniki: Badanie na postawie przypadku 54-letniego mężczyzny, u którego wystąpiła nagła głuchota. Obustronne przerzuty czerniaka stwierdzono na podstawie badania MRI i punkcji lędźwiowej. Pacjent zmarł po 3 miesiącach po zakończeniu leczenia.

Wyniki: Przerzuty czerniaka należy traktować jako przyczynek w niedosłuchu odbiorczym. Z przeglądu literatury specjalistycznej wynika, że średni czas przeżycia pacjentów z obustronnym przerzutem czerniaka w kącie mostowo-móżdżkowym wynosi 6 miesięcy po zakończeniu leczenia. Guzy te są w dużej mierze nieoperacyjne i chirurgicznie niemożliwe do oddzielenia od nerwów czaszkowych grupy VII i VIII. Interwencja chirurgiczna nie zwiększa prawdopodobieństwa przeżycia lub objawowych korzyści. Leczenie powinno skupiać się na utrzymaniu jakości życia. Rehabilitacja słuchu i radiochirurgia mogą przynieść pozytywne skutki.

Słowa kluczowe: słuch • czerniak • kąt mostowo-móżdżkowy

\section{Background}

Hearing loss of rapid onset is not an uncommon otolaryngological presentation, occurring at an annual incidence of around 5-20 per 100,000 population [1]. Over two-thirds is idiopathic in origin, other major causes including infection, vascular events, and trauma [2]. Only about $2 \%$ of cases are of neoplastic origin, the majority of these comprising vestibular schwannomas [2]. We describe a rare case of bilateral cerebellopontine angle melanoma causing bilateral sensorineural hearing loss, and present a review of the literature regarding survival and potential treatment.

\section{Case Report}

A 54-year-old man presented to our clinic with a 6-week history of progressive bilateral hearing loss and a feeling of imbalance. On otoscopy, both tympanic membranes and middle ears looked normal. His facial nerve function was unaffected. His pure tone audiogram demonstrated bilateral profound sensorineural hearing loss (Figure 1), with significant progression from the moderate hearing loss described at referral only 2 weeks previously. No baseline pure tone audiogram was available on record for this patient, as hearing had not been a significant symptom previously to cause him to seek medical attention. 
A

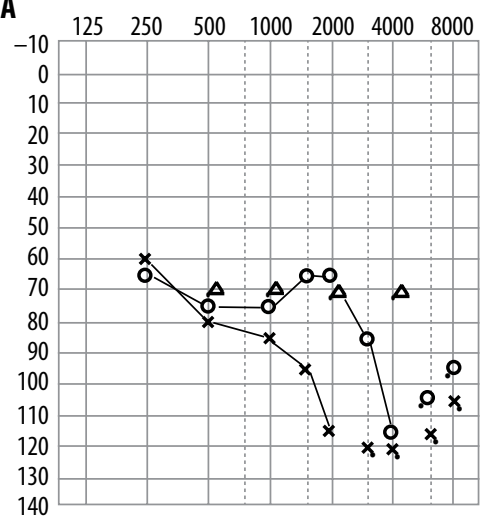

B

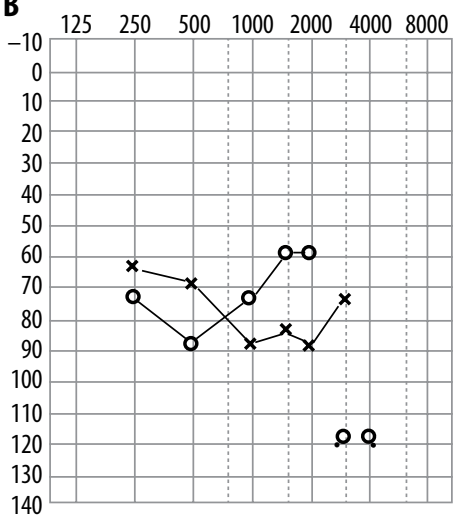

C

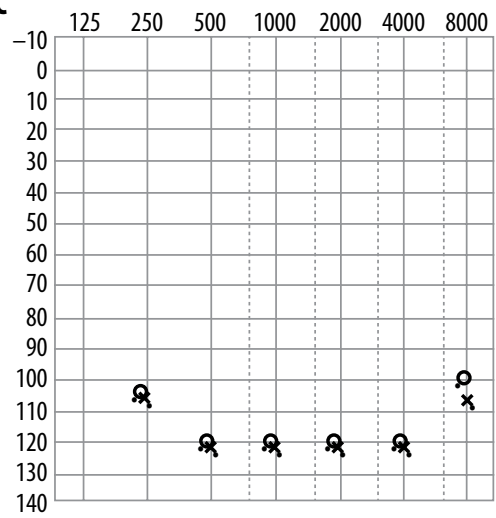

Figure 1. (A) Pure tone audiogram at initial ENT clinic appointment. (B) Pure tone audiogram at 4 weeks. (C) Pure tone audiogram at 6 weeks showing profound hearing loss throughout the full range of frequencies. ( $x$-axis, frequency $(\mathrm{Hz}) ; y$-axis, dB hearing loss)

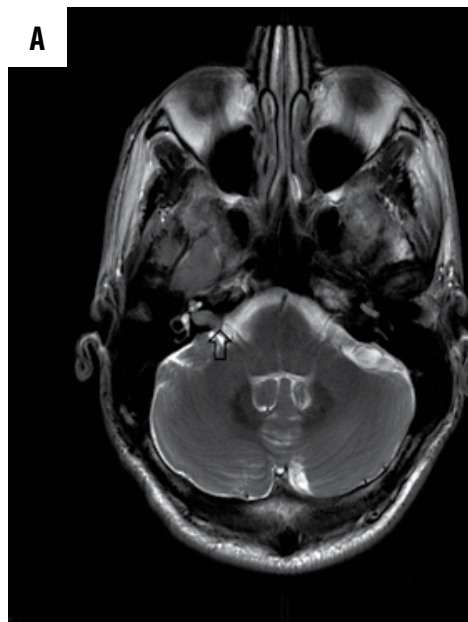

B

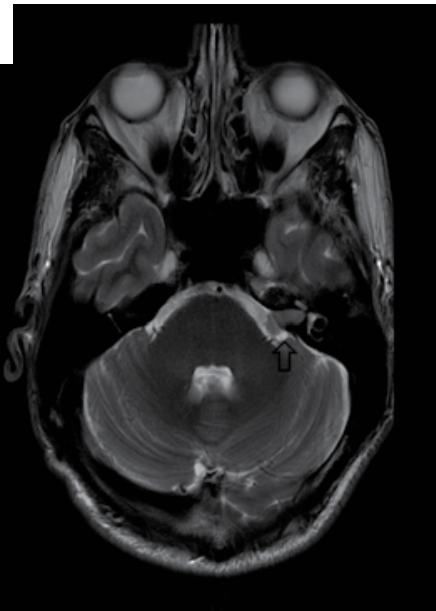

C

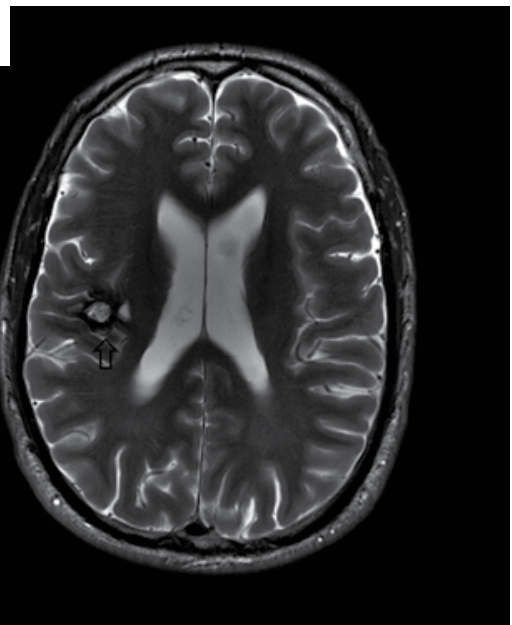

Figure 2. T2 axial MRI images. (A, B): Cerebellopontine angle lesions (arrows) arising from the internal auditory meati. (C) Right frontal intrinsic hemorrhagic lesion (arrow) characteristic of melanoma metastases

He had a past medical history of a $1.3 \mathrm{~mm}$ Clark Level 4 melanoma, which had been excised from behind his left ear some 12 years ago, and a radical neck dissection secondary to a recurrence of the melanoma on his left neck 6 years earlier. A chest CT at this time demonstrated multiple pulmonary nodules, which were resected via a median sternotomy. A right parietal metastasis diagnosed 4 years before presentation had been treated with stereotactic radiotherapy. This had shown no progression on repeat MRI scans, the latest of these 3 months before recent symptoms began.

Three days before his appointment was due, he developed severe headaches. An urgent CT head with contrast displayed enhancement within both internal auditory meati (IAM) was done. An MRI head was arranged, which confirmed bilateral gadolinium enhancing lesions within the IAM, extending to the cerebellopontine angles (CPA) (Figure 2). Atypical cells found in CSF from a lumbar puncture confirmed the diagnosis of malignant meningitis secondary to metastatic melanoma.

The patient began a course of oral steroids and he was referred for behind-the-ear hearing aids. However, 1 month later he reported complete deafness, and progression of pure tone audiograms was recorded over this time (Figure 1). No further audiometry was undertaken as diagnosis of pathology was confirmed by MRI scanning. At diagnosis, he was referred urgently to medical oncology for further treatment. He underwent gamma knife surgery (GKS) at another hospital. Two days after this treatment, he was admitted to hospital acutely confused. Repeat MRI demonstrated response of both IAM lesions to GKS, but also displayed enhancement of cerebellar folia, consistent with meningeal spread of metastases (Figure 3).

He was discharged home after recovering spontaneously from this episode of confusion, but continued to deteriorate, and died of metastatic melanoma 3 months later, and 5 months after initial referral.

\section{Discussion}

We describe both a rare cause of bilateral sensorineural hearing loss and an unusual presentation of metastatic melanoma. The majority of neoplasms at the CPA are vestibular schwannomas [3]. Metastatic tumours found at the CPA constitute only $0.2 \%$ of lesions found at this site and 


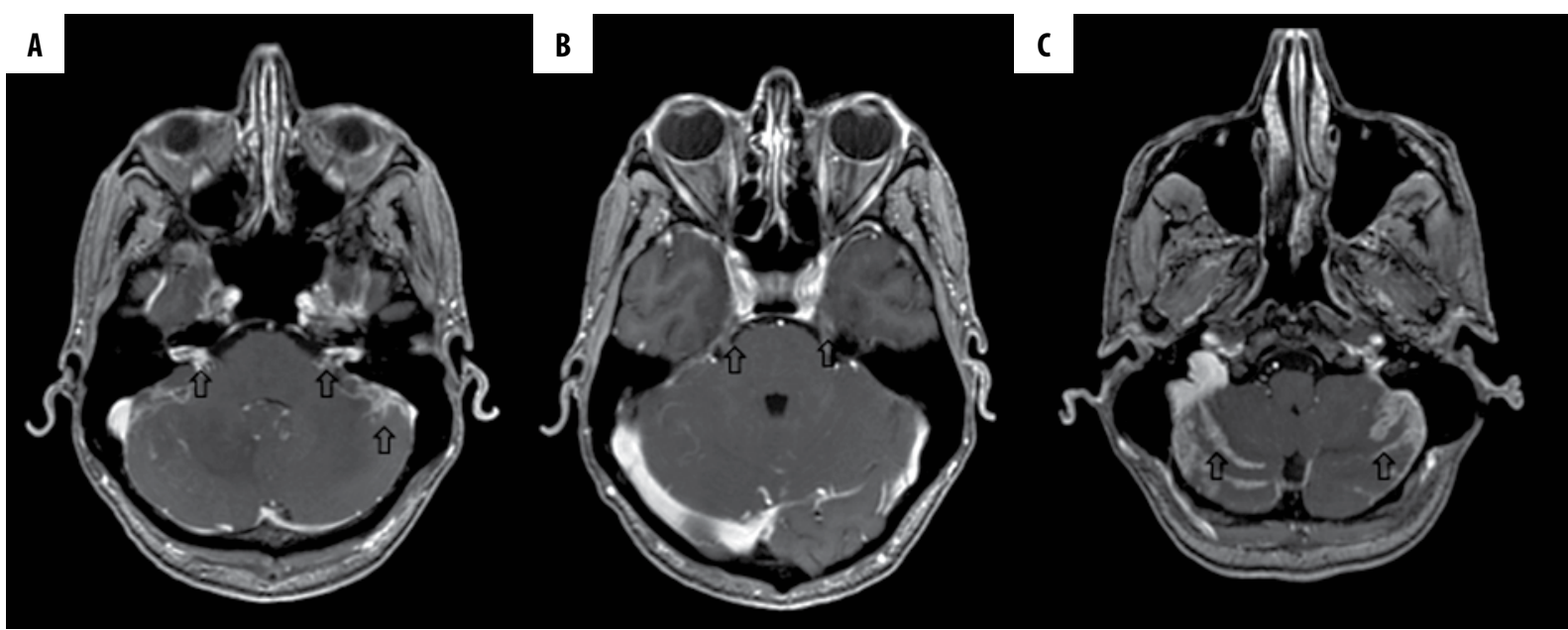

Figure 3. T1 axial MRI images post-gadolinium contrast. (A) Bilateral lesions (arrows) within the internal acoustic meati and cerebellar leptomeningeal enhancement. (B) Bilateral $5^{\text {th }}$ nerve enhancement (arrows) within the prepontine cistern. (C) Extensive leptomeningeal contrast enhancement of the cerebellar folia bilaterally (arrows) in keeping with infiltration

Table 1. Summary of previously published case reports of bilateral acoustic melanomas. All cases developed further intracranial metastasis following initial diagnosis

\begin{tabular}{|c|c|c|c|c|}
\hline $\begin{array}{l}\text { First author, } \\
\text { date of publication }\end{array}$ & $\begin{array}{l}\text { Extra-cranial } \\
\text { metastasis }\end{array}$ & $\begin{array}{c}\text { Development of } \\
\text { additional intracranial } \\
\text { metastasis }\end{array}$ & $\begin{array}{l}\text { Treatment } \\
\text { modality }\end{array}$ & $\begin{array}{l}\text { Survival post-treatment } \\
\text { (months) }\end{array}$ \\
\hline Harbart, 1969 [6] & Yes & Yes & Surgical & 6 \\
\hline Delerue, 1991 [7] & No & $\mathrm{n} / \mathrm{d}$ & Surgical & 4 \\
\hline Tu, $1994[8]$ & Yes & Yes & $n / d$ & $n / d$ \\
\hline Arriaga, 1995 [9] & No & $n / d$ & Surgical & 5 \\
\hline Shinogami, 1998 [10] & No & Yes & Surgical, radiotherapy & 12 \\
\hline Lee, 2005 [5] & No & Yes & Radiotherapy, chemotherapy & 3 \\
\hline Jacob, 2007 [11] & No & Yes & Surgical & 0 \\
\hline Brackmann, 2007 [12] & Yes & Yes & Radiotherapy & 9 \\
\hline Brackmann, 2007 [12] & Yes & Yes & GKS, Chemotherapy & 10 \\
\hline Brackmann 2007 [12] & No & $n / d$ & $\mathrm{n} / \mathrm{d}$ & $\mathrm{n} / \mathrm{d}$ \\
\hline Gerganov, 2008[4] & Yes & $n / d$ & Surgical & $\mathrm{n} / \mathrm{d}$ \\
\hline
\end{tabular}

$\mathrm{n} / \mathrm{d}$ - not described within paper

these most commonly originate from breast, lung, kidney, stomach, and larynx [3]. A systematic literature review (Medline database search terms used were 'cerebellopontine angle', 'melanoma', 'internal auditory meatus', and 'bilateral') identified nine papers which reported 11 cases of bilateral cerebellopontine angle metastatic melanoma [4-12]. Details of these cases are summarised in Table 1.

Recent data suggests incidence of malignant melanoma within the UK continues to increase and is now at around 17 cases per 100,000 population per year [13]. Melanoma is a common cause of intracerebral metastasis and $50 \%$ of patients with metastatic melanoma have cerebral involvement [14]. Despite this, melanoma rarely presents at the CPA. It has been suggested that metastasis to this site is haematological; at autopsy, metastatic melanoma has been found around blood vessels of the temporal bone [15]. From the temporal bone, metastatic melanoma is thought to track along cranial nerves VII and VIII via their neural sheaths or vasa nervosum [15]. This case also describes the progression of melanoma metastases to the posterior cranial fossa from the IAM, suggestive of leptomeningeal spread from this site. It is still unclear why the majority of such melanomas present bilaterally.

Vestibular schwannomas present as bilateral disease in $5 \%$ of cases; this occurs mainly in patients with neurofibromatosis type II [10]. Accordingly, there have been cases of misdiagnosis of bilateral cerebellopontine angle melanoma as both vestibular schwannoma [4] and neurofibromatosis type II [5]. Furthermore, diagnosis of metastasis to the CPA is not immediately obvious due to a latent 


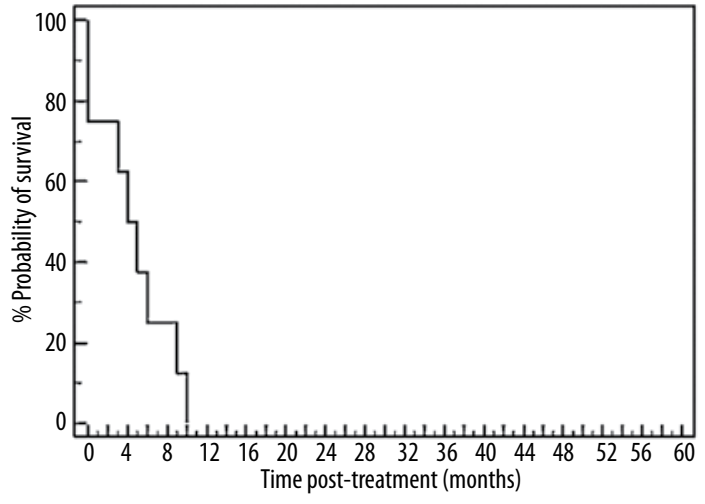

Figure 4. Kaplan-Meier survival curve for bilateral melanoma metastases

period, often of many years, between first diagnosis of cutaneous melanoma and cerebral presentation [4-12]. Metastatic malignant melanoma of the cerebellopontine angle distinguish themselves from vestibular schwannoma by the rapid onset of symptoms. Patients present with a very short history of bilateral hearing loss, often over the course of a few weeks associated with variable degrees of facial palsy and often symptoms of tinnitus, dysphagia, vertigo, and headache [1-12]. At the most extreme, one case described a progression to bilateral profound sensorineural loss within 1 week [11]. This is in contrast to vestibular schwannomas, which have a slowly progressive natural history, with only $25 \%$ of tumours growing by $>2 \mathrm{~mm}$ in the first year after diagnosis [16].

Survival after diagnosis of cerebral metastatic melanoma metastasis is a median of 2.3-6.0 months despite use of treatment modalities, and 4.3 months if a patient presents with neurological symptoms [17]. Bilateral CPA melanoma has a median survival of 6 months post treatment, highlighting that this diagnosis is virtually pre-terminal, despite treatment [4-12]. We generated a Kaplan-Meier survival curve for bilateral acoustic melanoma by inputting survival data post-treatment from previous case reports [4-12] (Figure 4).

This leads us to discuss the use of different treatment modalities for bilateral CPA melanoma. Melanoma is characteristically radio- and chemotherapy resistant. Evidence suggests surgical intervention is an independent factor for increasing survival in patients with metastatic melanoma to the brain, but all studies have been retrospective, and it is acknowledged that selection bias may play a large role in these results [17]. Prognosis is poor for patients who present with neurological symptoms, and those with extracranial and leptomeningeal metastases, among other factors [17]. Of all cases described, all presented with neurological symptoms, $50 \%$ were simultaneously found to have widespread extracranial metastases, and all patients developed additional intracerebral metastases after diagnosis (Table 1). This indicates that this group of patients may not show survival benefit from surgical intervention.

CPA melanoma is almost invariably found invading cranial nerves VII and VIII at surgery $[4,7,9,11]$. This is in contrast to benign tumours, which produce cranial nerve palsy by compression [17]. Accordingly, surgical resection of melanoma may be associated with significant morbidity, namely complete hearing loss and facial palsy [4,9]. Only Gerganov et al. [4] and Shingoami et al. [10] reported unilateral hearing preservation as a result of tumour resection from the IAM; in both cases the tumour was separate from the cranial nerves at surgery. It is interesting to note that for the same patients there was complete infiltration of contralateral cochlear nerves at surgery; these nerves were resected with resultant unilateral loss of hearing $[4,10]$. This is testament to the aggressive nature of malignant melanoma. Early intervention may not have symptomatic benefit; unresectable nerve infiltration is found within 2 weeks of symptom onset [11].

In the absence of clear symptomatic or survival benefit from surgical intervention, the role of GKS must be considered. GKS causes arrest of growth of tumours as a palliative measure. Retrospective studies show GKS to be at least as effective for survival as surgical intervention and to cause less morbidity [18]. In terminal disease where quality of life is perhaps of greater importance than quantity of life, there may be a role for GKS.

Hearing rehabilitation must also be considered as an important intervention for maintaining quality of life. In our case, a behind-the-ear hearing aid was offered, which provided short-term hearing improvement. Due to progressive infiltration of the auditory nerve by tumours and the poor prognosis, cochlear implantation does not seem warranted.

\section{Conclusions}

In summary, bilateral cerebellopontine angle metastatic melanoma should be suspected in patients with rapid onset hearing loss and a previous diagnosis of cutaneous melanoma, regardless of the length of the intervening period. This is particularly important given the increasing incidence of malignant melanoma worldwide. Maintaining quality of life is the main focus for treatment, with timely hearing rehabilitation and treatment with GKS favored over surgical intervention.

\section{References:}

1. Stachler RJ, Chandrasekhar SS, Archer SM, Rosenfeld RM, Schwartz SR, Barrs DM et al. Clinical practice guideline: sudden hearing loss. Otolaryngol Head and Neck Surgery, 2012; 146: S1-35.

2. Chau JK, Atashband S, Lin JRJ, Irvine RA, Westerberg BD. Systematic review of the evidence for the etiology of adult sudden sensorineural hearing loss. Laryngoscope, 2010; 120: 1011-21.
3. Brackmann DE, Bartels LJ. Rare tumours of the cerebellopontine angle. Otolaryngol Head Neck Surg, 1976; 88: 555-9.

4. Gerganov VM, Hore N, Herold C, Wrede K, Stan AC, Samii A et al. Bilateral malignant melanoma metastases to the internal auditory canal/cerebellopontine angle: surgical management and preservation of function. Case Report. J Neurosurg, 2008; 108: 803-7. 
5. Lee W, Weber PC. Melanoma metastasis masquerading as bilateral acoustic neuromas. Otolaryngol Head and Neck Surg, 2005; 132: 505-6.

6. Harbart F, Liu JC, Berry RG. Metastatic malignant melanoma to both VIII nerves. J Laryngol Otol, 1969; 83: 889-98

7. Delerue O, Destee A, Devos P. Bilateral metastases in the cerebellopontine angle. J Neurol Neurosurg Psychiatry, 1991; 54: 562-3

8. Tu AS, Wang H, Harris-McCorkle L, Saunders JR. Bilateral involvement of the cerebellopontine angles by malignant melanoma metastasis: a case report. Md Med J, 1994; 43: 967-70.

9. Arriaga A, William W, Brackmann D. Metastatic melanoma to the cerebellopontine angle. Clinical and imaging characteristics. Arch Otolaryngol Head Neck Surg, 1995; 121: 1052-6.

10. Shinogomi M, Yamasoba T. Bilateral isolated metastasis of malignant melanoma to the cerebellopontine angle. Otolaryngol Head and Neck Surg, 1998; 118: 276-9.

11. Brightman JA, Welling RP, Bradley D. Bilateral cerebellopontine angle metastatic melanoma: a case report. Ear Nose Throat J, 2007; 86: 388-90.

12. Brackmann DE, Doherty JR. CPA melanoma: diagnosis and management. Otol Neurotol, 2007; 28: 529-37.
13. Cancer Research UK. Skin Cancer Incidence Statistics. http:// www.cancerresearchuk.org/cancerinfo/cancerstats/types/skin/ incidence/. Published April 2013., Accessed accessed 19 May, 2013.

14. Amer MH, Al-Sarraf M, Baker LH, Vaitkevicius VK. Malignant melanoma and central nervous system metastases: incidence, diagnosis, treatment and survival. Cancer, 1972; 42: 660-8.

15. Navarette CM, Ruah CB, Schachern P, Paparella MM. Normal and metastatic melanin in the temporal bone. Am J Otolaryngol, 1995; 16: 33-9.

16. Eljamel S, Hussain M, Eligamel M. Should initial surveillance of vestibular schwannoma be abandoned? Skull Base Surg, 2011; 21: 59-64.

17. Raizer JJ, Hwu WJ, Panageas KS, Wilton A, Baldwin DE, Bailey $\mathrm{E}$ et al. Brain and leptomeningeal metastases from cutaneous melanoma: survival outcomes based on clinical features. Neuro Oncol, 2008; 10: 199-207.

18. Skeie BS, Skeie GO, Enger PØ, Ganz JC, Heggdal JI, Ystevik $B$ et al. Gamma knife surgery in brain melanomas: absence of extracranial metastases and tumor volume strongest indicators of prolonged survival. World Neurosurg, 2011; 75: 684-91. 